\title{
Correction to: Discrimination Matters: Relations of Perceived Discrimination to Student Mental Health
}

\author{
Mollie R. Weeks ${ }^{1}\left[\right.$ ] Amanda L. Sullivan ${ }^{1}$
}

Published online: 12 September 2020

○) Springer Science+Business Media, LLC, part of Springer Nature 2020
"Specifically, non-Hispanic Black children who experienced racial discrimination were approximately two and a half times as likely than non-Hispanic White children who did not experience discrimination to have identified anxiety problems."

The author apologizes for this mistake.

Publisher's Note Springer Nature remains neutral with regard to jurisdictional claims in published maps and institutional affiliations.

The original article can be found online at https://doi.org/10.1007/ s12310-019-09309-1.

\section{Mollie R. Weeks}

Linkx082@umn.edu

1 Department of Educational Psychology, School Psychology Program, College of Education and Human Development, University of Minnesota - Twin Cities, 56 E River Rd., 250 Education Sciences Building, Minneapolis, MN 55455, USA 